\section{Applying safeguards of research integrity to unethical organ donation and transplantation}

\author{
Katrina A Bramstedt (1) 1,2
}

Higgins' et al recent paper $^{1}$ presents a well-thought ethical analysis of the problems associated with the publication of unethical transplant research. More generally, research ethics committees never allow the use or reuse of data that has been collected without their required approval. Similarly, in many judicial settings, evidence is generally inadmissible when it is gathered illegally. ${ }^{2}$ Thus, journals and other publishers should follow in their footsteps and also roadblock any associated publications.

Moreover, unethical organ donation and transplantation research is rife with integrity issues, which violate publication norms (eg, fabrication or falsification of the source of the donor organs; absent informed consent of living donors or donor families; funder conflict of interest). If these normally accepted exclusions ${ }^{3}$ are ignored, then publishers are turning off their moral compass and facilitating an attitude of 'anything goes' in the conduct of research. Table 1 presents a timeline of scholarly responses to the problem of publishing unethical transplant research. As shown, since 2007 there has been a slow evolution of changing publisher practices, yet more progress must be made, especially by the transplant journals published in China.

Even if manuscript is blocked from publication (or later retracted), the existence of unethical data remains an ethical problem. What should be done with data that have already been collected by way of unethical organ donation and transplantation practices? If it is not fit to be published, then it could be argued to be not fit for use (including sharing with others) and should be destroyed. The same could also be said for such human organ/tissue specimens stored in

'Luxembourg Agency for Research Integrity, Esch-surAlzette, Luxembourg

${ }^{2}$ Health Advocate \& Professional Theme, Bond University School of Medicine, Gold Coast, QLD 4226, Australia

Correspondence to Professor Katrina A Bramstedt, Bond University School of Medicine, Gold Coast, QLD 4226, Australia; txbioethics@yahoo.com biorepositories. As an example, in USA, the Comprehensive Transplant Center at Wexner Medical Center is home to a transplant data and specimen repository, which is governed by human research ethics regulations. ${ }^{4}$ These regulations, as well as a governance structure, are in place to ensure ethical sourcing, storage and sharing of data and specimens. Chinese transplant centres should also incorporate these measures and ensure their repositories are subject to audit to verify ethical and regulatory adherence.

Open access databases are becoming popular in the field of medicine. Table 2 shows the volume of datasets pertaining to organ donation and transplantation in the free, open access repository Figshare (www.Figshare.com). According to the 'Rules and Conduct' of their terms and conditions, ${ }^{5}$ users 'shall not (and shall not permit any third party to) either (a) take any action or (b) upload, download, post, submit or otherwise distribute or facilitate' content that is unlawful, false or untruthful, offensive or deceptive. Figshare also has the right to remove content and suspend user accounts. Organ donation and transplant data could be deemed 'offensive' (causing hurt, upset, insult or anger) if it arises amid research ethics violations (eg, executed prisoners as donors, lack of informed consent, commercial organ sales). Accordingly, any suspect data should be removed and quarantined by data repositories and referred for investigation. The data owner might take his/ her data to another repository platform; however, an investigation (with subsequent institutional notification) could prevent that until the dataset is deemed ethically robust.

Agreeing with Higgins' et al, ${ }^{1}$ research misconduct investigations pertaining to unethical organ donation and transplant data can be performed by the researcher's host institution. However, national research integrity agencies often also provide these investigative services and they do so with less conflict of interest because they lack the shared institutional affiliation with the researcher. ${ }^{6}$ Shared affiliation can lead to problems with pressure or coercion of investigation team members due to their employment status (ie, harassment or interference with employment or promotion). When available, these independent organisations should lead and perform research misconduct investigations.

Higgins et al did well to draw similarities between the dilemma of Holocaust medical experimentation data to that of unethical transplant research data. ${ }^{1}$ One notable difference is that with regard to the unethical medical experiments that occurred with Nazi researchers during World War II, there are victim survivors

\begin{tabular}{|c|c|c|}
\hline Year & Scholar group & Recommendation \\
\hline 2007 & Rakela and Fung ${ }^{9}$ (USA) & $\begin{array}{l}\text { Manuscripts submitted to the journal, Liver Transplantation, shall explicitly exclude both executed } \\
\text { prisoners and paid organ donors. }\end{array}$ \\
\hline 2008 & Bramstedt and $\mathrm{Xu}^{10}$ (USA) & $\begin{array}{l}\text { Created guidelines for authors, editors and peer reviewers for organ donation and transplant } \\
\text { manuscripts to prevent publication of unethical research. }\end{array}$ \\
\hline 2012 & Caplan et al ${ }^{11}$ (USA) & $\begin{array}{l}\text { Journal of Clinical Investigation will require manuscripts about human organ transplantation in China to } \\
\text { include an attestation that the organ sources are not executed prisoners. }\end{array}$ \\
\hline 2013 & Valapour et al ${ }^{12}$ (USA) & $\begin{array}{l}\text { (1) Limit publishing of transplant research involving prisoners, in general and (2) ban publishing of } \\
\text { transplant research involving executed prisoners. }\end{array}$ \\
\hline 2017 & Editorial Board ${ }^{13}$ & $\begin{array}{l}\text { American Journal of Transplantation refuses to publish articles if the data are derived from an executed } \\
\text { prisoner. }\end{array}$ \\
\hline 2017 & Editorial Board ${ }^{14}$ & $\begin{array}{l}\text { Transplantation Direct requires that all procedures and studies described in manuscript submissions } \\
\text { 'have involved no illegal commercial transactions, the use of organs or other material from executed } \\
\text { prisoners, or other unethical practices in obtaining donor organs'. }\end{array}$ \\
\hline 2017 & Editorial Board ${ }^{15}$ & $\begin{array}{l}\text { Transplantation requires that all procedures and studies described in manuscript submissions 'have } \\
\text { involved no illegal commercial transactions, the use of organs or other material from executed prisoners, } \\
\text { or other unethical practices in obtaining donor organs'. }\end{array}$ \\
\hline 2019 & Editorial Board $^{16}$ & $\begin{array}{l}\text { Journal of Healrt and Lung Transplantation refuses to publish articles if the data are derived from an } \\
\text { executed prisoner. }\end{array}$ \\
\hline 2019 & $\begin{array}{l}\text { Bramstedt and } \mathrm{Xu}^{17} \\
\text { (Luxembourg, Australia, USA) }\end{array}$ & $\begin{array}{l}\text { Chinese journals should have rules that exclude data sourced from unethical organ donation and } \\
\text { transplantation. }\end{array}$ \\
\hline 2019 & $\begin{array}{l}\text { Rogers et al }{ }^{18} \text { (Australia, USA, New } \\
\text { Zealand) }\end{array}$ & Published papers containing unethical transplant research should be retracted. \\
\hline 2020 & $\begin{array}{l}\text { Higgins et al' (Australia, Singapore, } \\
\text { New Zealand) }\end{array}$ & $\begin{array}{l}\text { Supports the retraction of Chinese transplant research that uses organs procured from non-consenting } \\
\text { executed prisoners, including prisoners of conscience. }\end{array}$ \\
\hline
\end{tabular}




\begin{tabular}{ll}
\hline $\begin{array}{l}\text { Table } 2 \\
2020\end{array}$ & Figshare dataset volume, 1 June \\
\hline $\begin{array}{l}\text { Keyword search (within category } \\
\text { Medicine) }\end{array}$ & $\begin{array}{l}\text { \# of } \\
\text { (allasets } \\
\text { countries) }\end{array}$ \\
\hline 'kidney transplant' & 451 \\
\hline 'liver transplant' & 373 \\
'heart transplant' & 130 \\
\hline 'organ transplant' & 241 \\
\hline 'organ donation' & 116 \\
\hline
\end{tabular}

who could be sensitively approached to learn their views about data sharing and publishing. ${ }^{7}$ In contrast, executed prisoners who were the source of 'donor' organs for transplant are deceased and we shall never know their views on this topic. We do not honour them by publishing the data derived from them, rather we honour the author who publishes the paper (another paper for his/her cv). Investigations, however, can bring forms of justice, thus investigating the dataset (before publishing happens) could be advantageous because such can lead to the destruction of data that is ethically corrupt (preventing its use and reuse). Note this in contrast to saving negative data, datasets with errors or data from experiments that need to be repeated for verification-these may still hold value. Lastly, investigations that prove misconduct involving human organ donors and transplant recipients should require a public record apology from the implicated researcher $(\mathrm{s}) .^{8}$

Twitter Katrina A Bramstedt @AskTheEthicist
Contributors I am the sole author.

Funding The author has not declared a specific grant for this research from any funding agency in the public, commercial or not-for-profit sectors.

Competing interests None declared.

Patient consent for publication Not required.

Provenance and peer review Commissioned; internally peer reviewed.

(c) Author(s) (or their employer(s)) 2020. No commercial re-use. See rights and permissions. Published by BMJ.

$$
\text { D Check for updates }
$$

To cite Bramstedt KA. J Med Ethics 2020;46:685-686.

Received 1 June 2020

Accepted 3 June 2020

Published Online First 13 August 2020

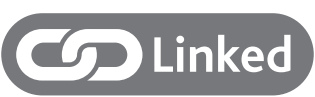

- http://dx.doi.org/10.1136/medethics-2019-106044 - http://dx.doi.org/10.1136/medethics-2020-106878

$J$ Med Ethics 2020;46:685-686.

doi:10.1136/medethics-2020-106535

\section{ORCID iD}

Katrina A Bramstedt http://orcid.org/0000-0001-54460123

\section{REFERENCES}

1 Higgins WC, Rogers WA, Ballantyne A, et al. Against the use and publication of contemporary unethical research: the case of Chinese transplant research. J Med Ethics 2020;46:678-84.

2 Beecher HK. Ethics and clinical research. N Engl J Med 1966;274(24):1354-60.

3 ALLEA European Federation of Academies of Sciences and Humanities. The European code of conduct for research integrity, 2017. Available: https://www.allea. org/wp-content/uploads/2017/05/ALLEA-EuropeanCode-of-Conduct-for-Research-Integrity-2017.pdf [Accessed 8 May 2020].

4 Wexner Medical Center. Comprehensive transplant center Biorepository. Available: https://wexnermedical. osu.edu/departments/surgery/research/ctcbiorepository [Accessed 1 Jun 2020].

5 Figshare. Terms and conditions, 2012. Available: https://figshare.com/terms [Accessed 1 Jun 2020].

6 Luxembourg agency for research integrity. Investigations. Available: https://lari.lu/lari-services/ investigations-cri-rules-of-procedure/ [Accessed 1 Jun 2020].

7 Conference on Jewish material claims against Germany. Personal statements from victims of Nazi medical experiments. Available: http://www. claimscon.org/about/history/closed-programs/medicalexperiments/personal-statements-from-victims/ [Accessed 1 Jun 2020].

8 Deša K. Letter of apology and notice of retraction. Croat Med J 2008;49(3):421.

9 Rakela J, Fung JJ. Liver transplantation in China. Liver Transp/ 2007;13(2):182-2.

10 Bramstedt KA, Xu J. China: A Case Study Regarding Transplant Publishing Issues. I Infor Ethics 2008;17(2):12-22.

11 Caplan AL, Rockman HA, Turka LA. Editorial position on publishing articles on human organ transplantation. J Clin Invest 2012;122(1):2-3.

12 Valapour M, Paulson KM, Hilde A. Strengthening protections for human subjects: proposed restrictions on the publication of transplant research involving prisoners. Liver Transp/ 2013;19(4):362-8.

13 American Journal of transplantation. Instructions to authors, 2017. Available: https://wol-prod-cdn. literatumonline.com/pb-assets/assets/16006143/ AJT_Instructions_to_Authors-1530282835830.pdf [Accessed 19 Feb 2019].

14 Transplantation. Instructions for authors, 2017. Available: http://edmgr.ovid.com/tpa/accounts/ifauth. pdf [Accessed 19 Feb 2019].

15 Transplantation direct. Instructions for authors, 2017. Available: http://edmgr.ovid.com/txd/accounts/ Transplantation_Direct_Instructions_for_Authors_ 2017.pdf [Accessed 19 Feb 2019].

16 Elsevier. The Journal of heart and lung transplantation author information, 2019. Available: https://www. jhltonline.org/content/authorinfo [Accessed 19 Feb 2019].

17 Bramstedt KA, XU J. A 10-year follow up of publishing ethics in China: what is new and what is unchanged. Res Integr Peer Rev 2019;4.

18 Rogers W, Robertson MP, Ballantyne A, et al. Compliance with ethical standards in the reporting of donor sources and ethics review in peer-reviewed publications involving organ transplantation in China: a scoping review. BMJ Open 2019;9(2):e024473. 